\title{
Mycoremediation potential of Pleurotus species for heavy metals: a review
}

\author{
Meena Kapahi $i^{1,2^{*}}$ (i) and Sarita Sachdeva ${ }^{1}$
}

\begin{abstract}
Mycoremediation is one of the biotechniques that recruits fungi to remove toxic pollutants from environment in an efficient and economical manner. Mushrooms, macro-fungi, are among the nature's most important mycoremediators. Pleurotus species (also called oyster mushrooms) are considered to be the most popular and widely cultivated varieties worldwide and this might be attributed to their low production cost and higher yields. Apart from their nutritive and therapeutic properties, Pleurotus species have high biosorption potential due to their extensive biomass, i.e. mycelial production. The genus has been reported to accumulate high levels of heavy metals. The current state-of-the art review mainly summarises previous investigations carried out by researchers on different roles and mechanisms played by Pleurotus species on heavy metals mycoremediation.
\end{abstract}

Keywords: Pleurotus species, Heavy metals, Biosorption, Mycoremediation, Laccase, Manganese peroxidase

\section{Introduction}

Indiscriminate use of chemicals has led to severe contamination of environmental segments by heavy metals. Heavy metals are non-biodegradable and tend to be biomagnified in the food chain (Singh et al. 2008). They pose a risk to human health when transferred via food chain and can further lead to toxic effects in organisms even in trace amounts. These metals can hinder different cellular processes. Their effects are generally concentration dependent and also differ with respect to individual toxicity. Hence, it becomes crucial to remove them prior to final discharge of effluents in environmental segments.

Conventional methods like chemical precipitation, adsorption, ion exchange, reverse osmosis and electrodialysis, to get rid of heavy metal burden of the environment, have their own shortcomings. These methods offer limitations like slow metal precipitation and incomplete removal (Aziz et al. 2015), generation of contaminated sludge requiring careful disposal (Gunatilake 2015; Ayangbenro 2017), high cost involved in the processes (Firdousi 2017), high energy and reagent requirements and clogging of membranes (Ahalya et al. 2003).

\footnotetext{
*Correspondence: meenakapahi@mru.edu.in

1 Department of Biotechnology, Manav Rachna International University, Sector 43, Faridabad 121004, India

Full list of author information is available at the end of the article
}

In this scenario, it is important to opt for an economically feasible and effective treatment method which is free from these limitations and is able to translate the need of removal of heavy metals in terms of eco-friendly approach. Bioremediation is a way of cleaning up heavy metals using biomass (or microorganisms) through the processes of biodegradation, biosorption, bioaccumulation and bioconversion operating in different ways (Kulshreshtha et al. 2014; Mosa et al. 2016). The microorganisms bind to heavy metals and concentrate them (Joutey et al. 2015). Biosorption is a passive process and heavy metals get adsorbed on the surface of the biosorbent (Velásquez and Dussan 2009) exhibiting the tolerance of biosorbent towards heavy metals. The mechanisms like extracellular (chelation and cell wall binding) and intracellular (binding to compounds like proteins) sequestration of heavy metals have been proposed as mechanisms for heavy metals tolerance in fungi (Fawzy et al. 2017). Biosorbent from mushrooms can be prepared from mycelium or fruit body (live or dead) and spent mushroom substrate (SMS). The factors like the presence of microbial population, the availability of contaminants to these organisms, metal ion concentration and environmental factors like temperature, $\mathrm{pH}$ and the presence of nutrients affect the biosorption process in totality (Prakash 2017). The process includes precipitation, ion 
exchange, electrostatic interaction, the redox process, etc. (Yang et al. 2015).

The biological process of remediation display features like economic viability (Ayangbenro 2017) and repeated use of biomass, selective metal binding, effective desorption and recycling of desorbents. Different microorganisms like algae, bacteria, fungi, yeast have been employed to carry out biosorption. The potential of fungal biomass as biosorbent has been accepted for the removal of heavy metals and radionuclides from polluted waters because of their excellent metal binding properties and tolerance towards metals and adverse environment like diverse $\mathrm{pH}$ and temperature conditions (Qazilbash 2004; Anand et al. 2006; Yazdani et al. 2010; Salman et al. 2014). Fungi have been reported to exhibit the ability to chemically modify or affect their bioavailability (Prakash 2017). Fungi have chitin in their walls which can tolerate high concentrations of metals and are capable of growing on medium at low $\mathrm{pH}$ and temperature exhibiting excellent mycoremediation potential.

Mushrooms, macro-fungi, have fruiting bodies that grow out of a mass of mycelium. They are a favourite delicacy in many parts of the world. The consumption of edible mushrooms is increasing due to a good content of proteins and trace minerals. Mushrooms have also been reported as nutraceuticals having anti-oxidant, anti-cancer, immunostimulatory, anti-inflammatory and anti-diabetic therapeutic properties (Barros et al. 2007; Kim et al. 2007; Sarikurkcu et al. 2008; Synytsya et al. 2009). These functional characteristics are mainly due to their chemical composition.

Apart from this, mushrooms can be employed for decontamination of the polluted environment. Mushrooms can build up heavy metals in high concentrations in their bodies above maximum permissible concentrations (Kalac and Svoboda 2000) and can act as an effective biosorption tool (Das 2005). High accumulation potential and shorter life span are some of the advantages of using mushrooms as biosorbents. Mushrooms belonging to the genera including Agaricus, Boletus, Armillaria, Polyporus, Russula, Pleurotus, Termitomyces have been investigated by some researchers for the uptake of heavy metals (Raj et al. 2011).

\section{Pleurotus species}

The genus Pleurotus, commonly called Oyster mushroom, is a type of gilled mushrooms which grows normally on wood. It encompasses many species, for example $P$. ostreatus, $P$. pulmonary, $P$. sajor-caju, $P$. cornucopiae, $P$. sapidus, $P$. platypus and $P$. ostreatoroseus. It is found all around the world, mainly in forest environments. The genus has enzymes like laccase (LAC) and
Mn-peroxidase (MnP), which degrade the lignocellulosic residues into food and enable them to grow on a variety of agricultural wastes with broad adaptability to varied agro-climatic conditions (Agrahar-Murugkar and Subbuakshmi 2005). A number of substrates like wheat straw, corn and sawdust can be used for its cultivation. They are popular and are widely cultivated throughout the world for food owing to simple production technology and their higher biological efficiency (Manzi et al. 2001). The genus is considered to be rich in proteins, fibres, carbohydrates, vitamins and minerals and owns a very pleasant taste. It is rich in immense therapeutic properties (Kalac and Svoboda 2000). There has been a rise in research activities related to the genus because of its multiple uses including biosorption.

\section{Pleurotus species-sequestering heavy metals}

Pleurotus species have been found to demonstrate a very effective biosorption potential for a wide range of environmental contaminants including heavy metals (Table 1). The accumulation of heavy metals in the fruit bodies tends to increase with an increase of the metals in the substrate (Ogbo and Okhuoya 2011). Heavy metals have become concentrated in certain areas, such as traffic congested highways, emission areas and cement- and battery-waste polluted sites. Pleurotus species growing near these polluted sites have the ability to accumulate heavy metals in high concentrations in their bodies. Mushrooms growing in heavily polluted areas like vicinity of the smelters have been reported to accumulate as much as 1540 times more than the background level of nickel (Barcan et al. 1998). The bioaccumulation potential of $P$. ostreatus from metal scrap sites has also been evaluated for $\mathrm{Cu}, \mathrm{Fe}, \mathrm{Zn}$ and $\mathrm{Mn}$ (Boamponsem et al. 2013). However, the accumulation potential of the species varies with the metallic species. Differences in accumulation potential for different heavy metals may be ascribed to the various types of growth substrates found in ecosystems. In a study conducted by Brunnert and Zadraz il (1983), more $\mathrm{Hg}$ than $\mathrm{Cd}$ has been found to be accumulated in fruiting bodies in P. ostreatus, while more $\mathrm{Cd}$ has been found in P. flabellatus. Purkayastha et al. (1994) reported highest uptake of $\mathrm{Cu}$ and $\mathrm{Cd}$ as compared to $\mathrm{Co}$ and acid $\mathrm{Hg}$ ions by $P$. sajor-caju. However, the uptake of $\mathrm{Cd}$ was reduced in the presence of $\mathrm{Cu}$ in P. sajor-caju owing to the chemical interference.

\section{Biosorption from the substrates}

They have the ability to enhance the nutritional content of the soil found in these areas (Adenipekun 2008) and bioremediate (Radulescu et al. 2010). A considerable decrease in $\mathrm{Cu}, \mathrm{Mn}$ and $\mathrm{Ni}$ in cement-contaminated 
soil and a slow decrease in lead content of battery-polluted soils in case of $P$. pulmonarius have been observed (Adenipekun et al. 2011). The bioaccumulation potential of $\mathrm{Hg}$ by $P$. ostreatus grown on artificial compost has also been studied by Bressa et al. (1988). Uptake and bioaccumulation studies have been done on Pleurotus species grown on metal-enriched substrates (Jain et al. 1988, 1989). Pleurotus sajor-caju, grown on metal-enriched substrate duckweed, has been found to accumulate $\mathrm{Cd}$ content above permissible limits (Jain et al. 1988).

\section{Heavy metals distribution after biosorption}

Subsequent to uptake, the metals are distributed unevenly within the fruiting bodies of mushrooms. The highest concentrations have been observed in the spore-forming part followed by rest of the cap and stipe (Gabriel et al. 1996). Cd has been found to be present in higher concentrations in caps $(22-56 \mathrm{mg} / \mathrm{kg}$ dry wt) than in stipe $(13-36 \mathrm{mg} / \mathrm{kg}$ dry wt) (Favero et al. 1990a) in $P$. ostreatus. The fruit body production has been found to be unaffected when exposed to a concentration up to $285 \mathrm{mg} \mathrm{Cd} / \mathrm{kg}$ of dried substrate. Cadmium has been found to be accumulated to a higher concentration of $20 \mathrm{mg} / \mathrm{g}$ dry weight in $P$. ostreatus when grown in liquid cultures of malt broth (Favero et al. 1991). Pleurotus species have been found to show resistance to high Cd concentrations (Gabriel et al. 1996). Their capacity to accumulate the heavy metals can lead to their immobilisation but ingestion by other organisms can result in transfer along food chain (Osman and Bandyopadhyay 1999). The amounts of $\mathrm{Pb}, \mathrm{As}, \mathrm{Fe}, \mathrm{Cd}$ and $\mathrm{Hg}$ in P. ostreatus available in the market (Accra, Ghana) have been found to be unsafe (Quarcoo and Adotey 2013).

\section{Factors affecting the biosorption process}

It has generated interest in the researchers to use the species for biosorption of heavy metals from wastewater. Influence of a range of operational parameters like $\mathrm{pH}$, temperature, biomass and initial metal ion concentrations and contact time have been considered while assessing their biosorption potential. The biosorption by the target species varies with the type of metal, its concentration and composition of substrate (Javaid and Bajwa 2008; Ogbo and Okhuoya 2011). In the biosorption study conducted by Adhikari et al. (2004), P. florida has been found to sorb heavy metals in the order of $\mathrm{Cd}>\mathrm{Cr}$ and to accumulate $1.2-2.5 \%$ more $\mathrm{Cd}$ than Fusarium oxysporum, Penicillium species and Aspergillus awamorii. The dead biomass can bind metals at levels higher, equivalent to or lesser than live biomass depending on the method used to kill the biomass (Zhu et al. 2010). Boamponsem et al. (2013) reported that the age of the fungal fruiting body or its size is of less importance in the accumulation of heavy metals by mushrooms. The interval between the fructifications affects the same. P. florida, P. ostreatus and $P$. djamour recorded the highest maximum accumulation (1.63-2.58 ppm) in the third flush of fructification (Dulay et al. 2015).

Pleurotus florida, P. ostreatus, P. sajor-caju, P. djamor, $P$. salmoneo-stramineus have been reported to be affected by $\mathrm{Pb}$. The concentration of $100 \mathrm{ppm}$ resulted in the lowest mycelial growth (Dulay et al. 2015). P. ostreatus have carboxylic, amino, thiol, phosphate and hydroxide groups on the cell wall helping in the biosorption of heavy metals (Banerjee and Nayak 2007; Javaid et al. 2011). IR analysis of lyophilised cells $P$. eryngii revealed the presence of carboxylic, amino, hydroxyl and methyl groups (Joo et al. 2011). P. ostreatus and P. sapidus have been reported to show affinity towards $\mathrm{Cu}$ and $\mathrm{Zn}$ as compared to $\mathrm{Cd}$ and $\mathrm{Pb}$ (Ita et al. 2006, 2008). This is in consensus with reports by Zhu et al. (2010). However, fruiting bodies of P. ostreatus immobilised in calcium alginate were shown to be effective in removing $\mathrm{Pb}$ and Co from solution (Xiangliang et al. 2005, 2009). P. ostreatus displayed tremendous removal potential in the order of $\mathrm{Ni}>\mathrm{Cu}>\mathrm{Cr}>\mathrm{Zn}$ ions from effluents of electroplating units (Javaid and Bajwa, 2008). P. floridianus and P. sajor-caju have been reported to exhibit affinity (biosorption efficiency) in the order of $\mathrm{Cd}>\mathrm{Zn}>\mathrm{Ni}>\mathrm{Pb}>\mathrm{Cu}>\mathrm{Fe}$ (Lamrood and Ralegankar 2013). Uptake of heavy metals by Azolla species and its further translocation in $P$. sajor-caju have been studied by Jain et al. (1989). Javaid et al. (2011) conducted a study to assess the biosorption potential of $P$. ostreatus in single and multi-metal ion systems for $\mathrm{Cr}, \mathrm{Cu}, \mathrm{Ni}$ and $\mathrm{Zn}$. Similarly, the SMS biosorbent of the species has been reported to exhibit higher selectivity for $\mathrm{Ni}$ than $\mathrm{Cu}$ in a bi-metal biosorption study conducted by Tay et al. (2016). P. sajor-caju has been demonstrated to remove metals like $\mathrm{Cu}, \mathrm{Fe}, \mathrm{Mg}, \mathrm{Mn}, \mathrm{Zn}$ (in the pro-degradant additive) on modified polyethylene films (Klein et al. 2012).

Both chemisorption and ion-exchange have been reported to be the involved mechanisms in metals biosorption. Lyophilised cells of $P$. eryngii showed higher bioconcentration values for $\mathrm{Pb}$ and $\mathrm{Cd}$ (Joo et al. 2011). Studies were conducted on removal of $\mathrm{Pb}, \mathrm{Zn}, \mathrm{Cu}$ and Mn from artificially contaminated soil using $P$. tuberregium. More than $90 \%$ of the metals were removed. There was a significant increase in the level of heavy metals in the pileus of the mushroom after biosorption process (Oyetayo et al. 2012). It has been reported to show preference towards $\mathrm{Fe}, \mathrm{Al}, \mathrm{Zn}$ and $\mathrm{Mn}$ followed by $\mathrm{Pb}$ and $\mathrm{Hg}$ (Nnorom et al. 2013). It has further been reported 
that $P$. tuber-regium has more bioaccumulative properties when grown from spawn rather than from sclerotia (Oghenekaro et al. 2008). In the packed bed column study on $\mathrm{Cd}$ employing $P$. platypus using industrial wastewater, the effect of parameters like bed depth and flow rate has been assessed (Vimala et al. 2011a). Biosorption of Cd by P. mutilus in packed bed column has also been done by Khitous et al. (2015). The packed biosorbent can be used for three regeneration cycles. Pleurotus SMS has been employed in a fixed bed study to remove $\mathrm{Mn}$ (II) ions from aqueous solutions. Flow rate of $1 \mathrm{ml} /$ min, bed height of $30 \mathrm{~cm}$, and metal ion concentration of $10 \mathrm{mg} / \mathrm{l}$ have been found to be suitable for biosorption (Kamarudzaman et al. 2015). Pleurotus species have also been assessed for the removal of different heavy metals from chemical laboratory waste in the form of live mycelia (Arbanah et al. 2012, 2013). The highest biosorption efficiency for $\mathrm{Fe}$ and $\mathrm{Cu}$ has been found to be 80.52 and $45.20 \%$, respectively (Arbanah et al. 2012). In a similar study conducted by Akyüz and Kirbað (2010), P. eryngii grown on various agro-wastes has been reported to show maximum uptake of $\mathrm{K}$ and the lowest of $\mathrm{Cu}$ contents.

The $\mathrm{pH}$ values of a solution should be considered as an important factor impacting the biosorption process. The $\mathrm{pH}$ influences the toxicity and solution chemistry of the heavy metals (Frutos et al. 2016), hydrolysis and complexation properties by bringing changes in ionic form (Deng et al. 2009). Hence, the ionic charge of the functional groups and the metal speciation at varied $\mathrm{pH}$ values affect biosorption process. Under acidic environment, positively charged metal ions get attached to the negatively charged biomass. Under high $\mathrm{pH}$, metal ions precipitate as metal hydroxides (Hlihor et al. 2014). The optimum $\mathrm{pH}$ for live and heat-inactivated P. sapidus encapsulated in calcium alginate beads has been found to be 6 (Yalçinkaya et al. 2002). In a study assessing the potential of $P$. ostreatus as a biosorbent in removing $\mathrm{Pb}(\mathrm{II})$ from electroplating industrial wastewater, the maximum $\mathrm{Pb}$ (II) biosorption of $92 \%$ in aqueous solution has been achieved at an unadjusted $\mathrm{pH}$ of 5.2 (Tay et al. 2009). Similarly, $\mathrm{pH}$ range of $2.5-6$ for the biosorption of $\mathrm{Ni}, \mathrm{Zn}, \mathrm{Cr}, \mathrm{Cu}, \mathrm{Fe}$ and $\mathrm{Pb}$ has been reported for P. ostreatus (Arbanah et al. 2012; Osman and Bandyopadhyay 1999; Tay et al. 2010). Tay et al. (2010) also carried out a study regarding the removal of $\mathrm{Pb}$ and $\mathrm{Cu}$ ions from aqueous solution. $\mathrm{Cu}(\mathrm{II})$ removal sharply increased from $38.21 \%$ at pH 2.0 to $81 \%$ at pH 5.0 in P. cornucopiae as reported by Danış (2010). The maximum biosorption of $\mathrm{Pb}$ (II) by $P$. ferulae with $\mathrm{pH}$ up to 3 , temperature $30^{\circ}$, and initial metal concentration $100 \mathrm{mg} / \mathrm{l}$ has been reported by Adebayo (2013). Optimum biosorption of divalence cations $[\mathrm{Ni}(\mathrm{II})$ and $\mathrm{Cu}(\mathrm{II})]$ by Pleurotus mushroom SMS has also been reported to be between $\mathrm{pH}$ of 5 and 6 (Tay et al. 2012). Pre-concentration and determination of $\mathrm{Cd}(\mathrm{II})$ and $\mathrm{Co}(\mathrm{II})$ in vegetables, using $P$. eryngii immobilised on Amberlite XAD-16 as a solid-phase biosorbent, have also been reported by Özdemir et al. (2012). The optimum extraction conditions were determined at a $\mathrm{pH}$ of 6.0 for $\mathrm{Cd}(\mathrm{II})$ and 5.0 for $\mathrm{Co}(\mathrm{II})$. In a similar study, $\mathrm{pH}$ range of 4-5 has been optimised for P. ostreatus immobilised on Amberlite XAD-4 for the biosorption of $\mathrm{Cr}$, $\mathrm{Cd}$ and $\mathrm{Cu}$ (Kocaoba and Arisoy 2011). In the research on hybrid of P. sajor-caju and sunflower waste biomass immobilised on sodium alginate, the maximum equilibrium uptake for lead was found to be at $\mathrm{pH} 4.5$ (Majeed et al. 2012). P. cornucopiae has been used to remove $\mathrm{Cr}$ from aqueous solution with bubbling fluidised bed $(\mathrm{Xu}$ et al. 2016).

Pre-treating the biomass with heat, alkalies or acids has a significant effect on the biosorption process depending upon the type of metal and fungal species. Pre-treatment of living biomass by physical and chemical methods resulted in an improvement in cadmium biosorption in comparison with living biomass of $P$. florida (Das et al. 2007). Methods like freeze drying (FD), oven drying (OD) and sun drying (SD) have been used for P. ostreatus for analysing the contents of different heavy and trace elements. Among the detected elements, $\mathrm{K}$ ranked the highest by $2.59,1.31$ and $2.30 \%$ in FD, OD and SD samples, respectively. OD biomass of $P$. ostreatus showed an increase in removal rate on increasing metal ion concentration (Javaid and Bajwa 2007). The other conditions affecting the biosorption as reported are ionic strength, other ions and complexing agents. The presence of high ionic strength and appreciable quantities of a complexing agent like EDTA significantly reduce the $\mathrm{Pb}(\mathrm{II})$ removal (Osman and Bandyopadhyay 1999).

\section{Heavy metals vis-a-vis effects}

The uptake of heavy metals has its consequent deleterious effects on the growth, productivity and cellular proteins. Gabriel et al. (1996) reported fructification of Pleurotus species in Cd-contaminated environment. Baldrian et al. (2000) demonstrated inhibition of mycelial penetration into soil by $\mathrm{Cd}$ and $\mathrm{Hg}$. Effect of $\mathrm{Hg}$ on the highest cadmium uptake (between 88.9 and 91.8\%) was observed with aerobic fungal biomass from the exponential growth phase in P. sajor-caju (Cihangir and Saglam 1999). Cadmium up to $150 \mu \mathrm{g} / \mathrm{ml}$ slowly inhibited mycelia development in case of $P$. ostreatus but never blocked it completely (Favero et al. 1991). Effect of $\mathrm{Hg}$ on the growth of wood-rotting basidiomycetes including $P$. 
ostreatus was studied by Mandal et al. (1998). The growth of the mushroom was significantly inhibited. Purkayastha et al. (1994) reported more than $85 \%$ reduction of growth in $P$. sajor-caju at 15 and $6 \mu \mathrm{g} / \mathrm{ml}$ of $\mathrm{Pb}(\mathrm{II})$ and $\mathrm{Hg}(\mathrm{II})$, respectively. $\mathrm{Pb}$ reduced mycelial protein significantly (36\%), but $\mathrm{Hg}$ caused maximum reduction (30\%) of proteins in sporocarps. $\mathrm{Pb}$ reduced biological efficiency of sporocarp production. Mercury has been reported to prevent growth and fruit body production in $P$. tuberregium, while stipe length, stipe diameter and cap diameter were affected by lead followed by cadmium (Akpaja et al. 2012). Mineral (Fe, $\mathrm{Zn}, \mathrm{Li}$ ) enrichment reduced anti-oxidant activity in $P$. ostreatus owing to polyphenol complexation with these elements leading to decreased free radical availability (Fontes et al. 2013).

\section{Heavy metals and enzyme regulation}

The saprotrophic basidiomycetes utilise a variety of extracellular enzymes including ligninolytic enzymes for the utilisation of complex nutrients (Kapoor and Viraraghavan 1998). Factors controlling enzyme production among white rot fungi have also been widely studied. The main factors that influence the enzyme production are the nutrients, inhibitory compounds, temperature and interrelationships with other fungi (Baldrian and Gabriel 2002). Extracellular ligninolytic and cellulolytic enzymes are regulated by heavy metals on transcription level and during the course of their action. The effect of the heavy metals on enzymatic activities influences the energy flux in the ecosystem. In a study, a positive regulation of laccase and isoenzymes on copper application has been reported in the case of P. ostreatus (Baldrian and Gabriel 2002; Palmieri et al. 2000). The Mn-peroxidase activity decreased with increasing $\mathrm{Cd}$ concentration, whereas activities of endo-1,4-L-glucanase, 1,4-L-glucosidase and laccase highly increased in the presence of metal (Baldrian and Gabriel 2003). It has been reported that the P. sajor-caju laccase isozyme genes (phenol oxidase A1b (POXA1b), POXA2 and POXC) are differentially regulated at the transcriptional level in response to copper and manganese (Collins and Dobson 1997; Soden and Dobson 2001). The addition of $\mathrm{Hg}$ has been found to decrease the activity of laccase immediately and reduce the stability of the enzyme (Collins and Dobson 1997; Baldrian and Gabriel 2002). Interestingly, $\mathrm{Cu}$ and also $\mathrm{Hg}$ increased $\mathrm{MnP}$ activity slightly. However, when incubated in the presence of all three metals, the activity of MnP decreased even at low concentrations of $\mathrm{Cd}$, $\mathrm{Cu}$ and $\mathrm{Hg}$ (Baldrian and Gabriel 2002) showing the synergetic effect of the heavy metals. Manganese has also been found to affect MnP gene transcription and enzyme activity in a positive way in some fungi like Pleurotus spp. (Ruiz-Duenas et al. 1999). A study was conducted by Drzewiecka et al. (2010) to assess the effect morphology and physiology of Pleurotus eryngii after incubating the spawn in the $\mathrm{Zn}-, \mathrm{Cu}-, \mathrm{Co}-, \mathrm{Cd}-$ and $\mathrm{Ni}$-enriched substrate. Laccase activity was stimulated by $\mathrm{Ni}$ and $\mathrm{Cu}$ even at low concentrations during incubation stage; but inhibited during fruiting stage. The inhibition effect was more pronounced when exposed to multi-metal solution.

To consider a fungal species as a biosorbent, desorption of the adsorbed metal ions and subsequent reuse and efficiency of the biomass in biosorption need to be taken into account. Acidic solution desorption has been reported to be more effective than alkaline solution desorption (Prasad et al. 2013). Under acidic conditions, protons compete for the sites releasing metal ions in the medium. Ninety-seven percent desorption of the adsorbed $\mathrm{Hg}$ from immobilised and heat-treated P. sajorcaju resulted when eluted with $\mathrm{HCl}$ (Arica et al. 2003). Ninety-nine percent of lead could be desorbed from $P$. ostreatus using $\mathrm{HCl}$ for a contact period of $1 \mathrm{~h}$. The used biomass of $P$. florida could be regenerated and reused for biosorption of lead for six times (Prasad et al. 2013). A regeneration rate of $59 \%$ of $\mathrm{Cu}$ has been reported for P. mutilus (Henini et al. 2011). However, they can be improved by coupling the chemical desorption method with a copper recovery; the regenerated biomass for a content $10 \mathrm{~g} / \mathrm{l}$ has a maximum adsorption capacity smaller but still significant $59.75 \mathrm{mg} / \mathrm{g}$.

\section{Conclusion}

Different methods are being adopted to remove heavy metals from wastewater. Keeping in mind the financial aspects, it is necessary to produce low-cost, effective and recyclable adsorbents for their widespread use. There are some limitations of using mushrooms for biosorption. Biosorption potential of different species is also being assessed in a comparative way. Looking at the amount of work done on Pleurotus spp., the species holds a promise to be used as a biosorbent for heavy metals. The degree of tolerance is different for the species for different heavy metals. For performance assessment studies in the future, multi-component sorption studies should be stressed upon as the industrial wastewater is a cocktail of metal ions in solution and that plays an important role in the sorption efficiency of the species. The biosorption potential of the species is yet to be tapped and used commercially. Mushrooms being a food crop and looking at the potential of mushroom mycelia, the SMS produced after harvesting the mushroom can be used for the mycoremediation of the degraded sites. The aged mycelia, SMS, are otherwise generated in huge amounts by the mushroom farms and pose a disposal problem. 
Table 1 Previous contributions of heavy metals biosorption using different forms of Pleurotus species

\begin{tabular}{|c|c|c|c|}
\hline Biosorbent type & Pleurotus species & Heavy metals & References \\
\hline Oven- and freeze-dried, autoclaved mycelia & P. florida & $\mathrm{Cd}$ & Das et al. (2007) \\
\hline \multirow[t]{5}{*}{ Oven-dried mycelia } & \multirow[t]{4}{*}{ P. ostreatus } & $\mathrm{Cr}$ & $\begin{array}{l}\text { Javaid and Bajwa (2007), Puentes- } \\
\text { Cárdenas et al. (2012) }\end{array}$ \\
\hline & & $\mathrm{Pb}$ & Tay et al. (2009), Liew et al. (2010) \\
\hline & & $\mathrm{Cd}$ & Tay et al. (2011) \\
\hline & & $\mathrm{Cu}, \mathrm{Cr}, \mathrm{Ni}, \mathrm{Zn}$ & Javaid et al. (2011) \\
\hline & P. florida & $\mathrm{Pb}$ & Prasad et al. (2013) \\
\hline \multirow[t]{8}{*}{ Live mycelia } & \multirow[t]{5}{*}{ P. ostreatus } & $\mathrm{Cd}$ & Favero et al. (1990a, b) \\
\hline & & $\mathrm{Hg}$ & Mandal et al. (1998) \\
\hline & & $\mathrm{Cu}, \mathrm{Cr}, \mathrm{Ni}, \mathrm{Zn}$ & Javaid and Bajwa (2008) \\
\hline & & $\mathrm{Cu}, \mathrm{Cr}, \mathrm{Fe}, \mathrm{Zn}$ & Arbanah et al. (2012) \\
\hline & & $\mathrm{Cr}$ & Arbanah et al. (2013) \\
\hline & $\begin{array}{l}\text { P. ostreatus, P. florida, P. djamour, P. salmoneo- } \\
\text { stramineus, P. cystidiosus }\end{array}$ & $\mathrm{Pb}$ & Dulay et al. (2015) \\
\hline & P. eryngii & $\mathrm{Mn}$ & Wu et al. (2016) \\
\hline & P. floridianus, P. sajor-caju & $\mathrm{Cu}, \mathrm{Cd}, \mathrm{Fe}, \mathrm{Ni}, \mathrm{Pb}, \mathrm{Zn}$ & Lamrood and Ralegankar (2013) \\
\hline \multirow[t]{5}{*}{ Biomass immobilised on calcium alginate } & \multirow[t]{3}{*}{ P. ostreatus } & $\mathrm{Pb}$ & Xiangliang et al. (2005) \\
\hline & & Co & Xiangliang et al. (2009) \\
\hline & & $\mathrm{Cu}, \mathrm{Pb}$ & de Almeida and Burgess (2013) \\
\hline & P. sapidus & $\mathrm{Cd}, \mathrm{Hg}$ & Yayçinkaya et al. (2002) \\
\hline & $\begin{array}{l}\text { P. sajor-caju and sunflower waste biomass } \\
\text { hybrid }\end{array}$ & $\mathrm{Pb}$ & Majeed et al. $(2012,2014)$ \\
\hline \multirow[t]{2}{*}{ Biomass immobilised on XAD-4 } & P. ostreatus & $\mathrm{Cu}, \mathrm{Cr}, \mathrm{Cd}$ & Kocaoba and Arisoy (2011) \\
\hline & P. eryngii & $\mathrm{Cd}, \mathrm{Co}$ & Özdemir et al. (2012) \\
\hline \multirow[t]{4}{*}{ SMS } & \multirow[t]{4}{*}{ P. ostreatus } & $\mathrm{Cu}$ & Tay et al. (2010) \\
\hline & & $\mathrm{Cr}$ & Carol et al. (2012) \\
\hline & & $\mathrm{Cu}, \mathrm{Ni}$ & Tay et al. $(2012,2016)$ \\
\hline & & $\mathrm{Cd}, \mathrm{Pb}, \mathrm{Cu}$ & Frutos (2016) \\
\hline \multirow[t]{10}{*}{ Fruit body accumulation } & \multirow[t]{2}{*}{ P. ostreatus } & $\mathrm{Cd}$ & Favero et al. (1990a, b) \\
\hline & & $\mathrm{Hg}$ & Bressa et al. (1988) \\
\hline & \multirow[t]{2}{*}{ P. cornucopiae } & $\mathrm{Cu}$ & Danis (2010) \\
\hline & & $\mathrm{Cr}$ & Xu et al. (2016) \\
\hline & P.platypus & $\mathrm{Cd}$ & Vimala and Das (2011b) \\
\hline & P. ostreatus, P. tuber-regium. & $\mathrm{Hg}$ & Nnorom et al. (2012) \\
\hline & P.ferulae & $\mathrm{Pb}$ & Adebayo (2013) \\
\hline & $\begin{array}{l}\text { P. ostreatus, P. florida, P. djamour, P. salmoneo- } \\
\text { stramineus, P. cystidiosus }\end{array}$ & $\mathrm{Pb}$ & Dulay et al. (2015) \\
\hline & P. eryngii & $\mathrm{Pb}$ & Jiang et al. (2016) \\
\hline & P. ostreatus & $\mathrm{Pb}$ & Jiang et al. (2017) \\
\hline Sun-dried fruit & P. ostreatus & $\mathrm{Pb}$ & Osman and Bandyopadhyay (1999) \\
\hline \multirow[t]{4}{*}{ Oven-dried fruit } & \multirow[t]{2}{*}{ P. ostreatus } & $\mathrm{Cu}$ & Huo et al. (2011) \\
\hline & & $\mathrm{Cu}, \mathrm{Pb}, \mathrm{Zn}, \mathrm{Mn}$ & Oyetayo et al. (2012) \\
\hline & P.platypus & $\mathrm{Cd}$ & Vimala and Das (2011b) \\
\hline & P.eous & $\mathrm{Cr}, \mathrm{Ni}, \mathrm{Pb}$ & Suseem and Mary Saral (2014) \\
\hline Freeze-dried fruit & P. eryngii & $\mathrm{Cd}, \mathrm{Pb}$ & Joo et al. (2011) \\
\hline
\end{tabular}

\section{Authors' contributions}

The authors (MK and SS) have made substantial contributions to conception and design, or acquisition of data, or analysis and interpretation of data, and they have been involved in drafting the manuscript or revising it critically for important intellectual content. The authors have given final approval of the version to be published. Each author should have participated sufficiently in the work to take public responsibility for appropriate portions of the content, and agreed to be accountable for all aspects of the work in ensuring that questions related to the accuracy or integrity of any part of the work are appropriately investigated and resolved. Both authors read and approved the final manuscript. 


\begin{abstract}
Author details
${ }^{1}$ Department of Biotechnology, Manav Rachna International University, Sector 43, Faridabad 121004, India. ${ }^{2}$ Manav Rachna University, Sector 43 Faridabad 121004, India.
\end{abstract}

\section{Acknowledgements}

NA.

\section{Competing interests}

The authors declare that they have no competing interests. The Editor may ask for further information relating to competing interests.

\section{Consent for publication}

The authors grant to any third party, in advance the right to use, reproduce or disseminate the article in its entirety or in part, in any format or medium, provided that no substantive errors are introduced in the process, proper attribution of authorship and correct citation details are given, and that the bibliographic details are not changed. If the article/book is reproduced or disseminated in part, this must be clearly and unequivocally indicated.

\section{Publisher's Note}

Springer Nature remains neutral with regard to jurisdictional claims in published maps and institutional affiliations.

Received: 11 April 2017 Accepted: 4 July 2017

Published online: 10 July 2017

\section{References}

Adebayo AO (2013) Investigation on Pleurotus ferulae potential for the sorption of $\mathrm{Pb}$ (II) from aqueous solution. Bull Chem Soc Ethiop 27:25-34

Adenipekun CO (2008) Bioremediation of engine-oil polluted soil by Pleurotus tuber-regium Singer, a Nigerian white-rot fungus. Afr J Biotechnol 7:55-58

Adenipekun CO, Ogunjobi AA, Ogunseye AO (2011) Management of polluted soils by a white-rot fungus: Pleurotus pulmonarius. Assumption Univ J Technol 15:57-61

Adhikari T, Manna MC, Singh MV, Wanjari RH (2004) Bioremediation measure to minimize heavy metals accumulation in soils and crops irrigated with city effluent. J Food Agric Environ 2(1):266-270

Agrahar-Murugkar D, Subbuakshmi G (2005) Nutritional value of edible wild mushrooms collected from the Khasi hills of Meghalaya. Food Chem 89:599-603

Ahalya N, Ramachandra TV, Kanamadi RD (2003) Biosorption of heavy metals. Res J Chem Environ 7(4):71-79

Akpaja EO, Nwogu NA, Odibo EA (2012) Effect of some heavy metals on the growth and development of Pleurotus tuber-regium. Mycosphere 3:57-60

Akyüz M, Kirbað S (2010) Element contents of Pleurotus eryngii (DC. ex Fr.) Quel. var. eryngii grown on some various agro-wastes. Ekoloji 19(74):10-14

Anand P, Isar J, Saran S, Saxena RK (2006) Bioaccumulation of copper by Trichodermaviride. Bioresour Technol 97:1018-1025

Arbanah M, Miradatul Najwa MR, Ku Halim KH (2012) Biosorption of Cr(III), $\mathrm{Fe}(\mathrm{II}), \mathrm{Cu}(\mathrm{II}), \mathrm{Zn}(\mathrm{II})$ ions from liquid laboratory chemical waste by Pleurotus ostreatus. Int J Biotechnol Wellness Ind 1:152-162

Arbanah M, Miradatul Najwa MR, Ku Halim KH (2013) Utilization of Pleurotus ostreatus in the removal of $\mathrm{Cr}(\mathrm{VI})$ from chemical laboratory waste. Int Refreed J Eng Sci 2(4):29-39

Arica MY, Arpa C, Kaya B (2003) Comparative biosorption of mercuric ions from aquatic systems by immobilized live and heat-inactivated Trametes versicolor and Pleurotus sajur-caju. Bioresour Technol 89:145-154

Ayangbenro Babalola (2017) A new strategy for heavy metal polluted environments: a review of microbial biosorbents. Int J Environ Res Public Health 14:94

Aziz HA, Adlan MN, Ariffin KS (2015) Heavy metals (Cd, Pb, Zn, Ni, Cu and $\mathrm{Cr}(\mathrm{III}))$ removal from water in Malaysia: post treatment by high quality limestone. Bioresour Technol 99(6):1578-1583
Baldrian P, Gabriel J (2002) Copper and cadmium increase laccase activity in Pleurotus ostreatus. FEMS Microbiol Lett 206:69-74

Baldrian P, Gabriel J (2003) Lignocellulose degradation by Pleurotus ostreatus in the presence of cadmium. FEMS Microbiol Lett 220:235-240

Baldrian P, In Der Wiesche C, Gabriel J, Nerud F, Zadražil F (2000) Influence of cadmium and mercury on activities of ligninolytic enzymes and degradation of polycyclic aromatic hydrocarbons by Pleurotus ostreatus in soil. Appl Environ Microbiol 66:2471-2478

Banerjee A, Nayak D (2007) Biosorption of no-carrier-added radio-nuclides by calcium alginate beads using 'tracer packet' technique. Bioresour Technol 98:2771-2774

Barcan VS, Kovnatsky EF, Smetannikova MS (1998) Absorption of heavy metals in wild berries and edible mushrooms in an area affected by smelter emissions. Water Air Soil Pollut 103:173-195

Barros L, Baptista P, Estevinho LM, Ferreira ICFR (2007) Bioactive properties of the medicinal mushroom Leucopaxillus giganteus mycelium obtained in the presence of different nitrogen sources. Food Chem 105:179-186. doi:10.1016/j.foodchem.2007.03.063

Boamponsem GA, Obeng AK, Osei-Kwateng M, Badu AO (2013) Accumulation of heavy metals by Pleurotus ostreatus from soils of metal scrap sites. Int J Curr Res Rev 5(4):01-09

Bressa G, Coma L, Costa P (1988) Bioaccumulation of Hg in the mushroom Pleurotus ostreatus. Ecotoxicol Environ Safe 16:85-89

Brunnert H, Zadraž il F (1983) The translocation of mercury and cadmium into the fruiting bodies of six higher fungi. A comparative study on species specificity in five lignocellulolytic fungi and the cultivated mushroom Agaricus bosporus. Eur J Appl Micorbiol Biotechnol 17:358-364

Carol D, Kingsley SJ, Vincent S (2012) Hexavalent chromium removal from aqueous solutions by Pleurotus ostreatus spent biomass. Int J Eng Sci Technol 4(1):7-22

Cihangir N, Saglam N (1999) Removal of cadmium by Pleurotus sajor-caju basidiomycetes. Acta Biotechnol 19:171-177

Collins PJ, Dobson A (1997) Regulation of laccase gene transcription in Trametes versicolor. Appl Environ Microbiol 63:3444-3450

Danış Ü (2010) Biosorption of copper(II) from aqueous solutions by Pleurotus cornucopiae. BALWOIS 2010, Ohrid, Republic of Macedonia, 25-29 May 2010

Das N (2005) Heavy metals biosorption by mushrooms. Indian J Natl Prod Resour 4:454-459

Das N, Charumathi D, Vimala R (2007) Effect of pretreatment on $\mathrm{Cd}^{2+}$ biosorption by mycelia biomass of Pleurotus florida. Afr J Biotechnol 6:2555-2558

de Almeida LK, Burgess JE (2013) Biosorption and bioaccumulation of copper and lead by Phanerochaete and Pleurotus ostreatus. http://www.ewisa. co.za/literature/files/182_133\%20Burgess.pdf. Accessed 20 June 2016

Deng L, Zhang Y, Qin J, Wang X, Zhu X (2009) Biosorption of Cr(VI) from aqueous solutions by nonliving green algae Cladophora albida. Miner Eng 22:372-377

Drzewiecka K, Siwulski M, Mleczek M, Golinski P (2010) The Influence of elevated heavy metals content in substrate on morphology and physiology of King Oyster mushroom (Pleurotus eryngii) effects on human health. In: 15th International conference on heavy metals in the environment. http://www.chem.pg.gda.pl/ichmet/

Dulay RMR, De Castro MAEG, Coloma NB, Bernardo AP, Cruz AGD, Tiniola RC, Kalaw SP, Reyes RG (2015) Effects and myco-remediation of lead (Pb) in five Pleurotus mushrooms. Int J Biol Pharm Allied Sci 4(3):1664-1677

Favero N, Bressa G, Costa P (1990a) Response of Pleurotus ostreatus to cadmium exposure. Ecotoxicol Environ Safe 20(1):1-6

Favero N, Costa P, Paolo Rocco G (1990b) Role of copper in cadmium metabolism in the basidiomycetes Pleurotus ostreatus. Comp Biochem Physiol Part C Comp Pharmacol 97(2):297-303

Favero N, Costa P, Massimino ML (1991) In vitro cadmium uptake by basidiomycetes Pleurotus ostreatus. Biotechnol Lett 13:701-704

Fawzy EM, Abdel-Motaal FF, EL-zayat SA (2017) Biosorption of heavy metals onto different eco-friendly substrates. J Toxicol Environ Health Sci 9(5):35-44

Firdousi SA (2017) Bioaccumulation and bio-absorptions of heavy metals by the mushroom from the soil. J Med Chem Drug Discov 2(3):25-33

Fontes Vieira PA, Gontijo DC, Vieira BC, Fontes EAF, Soares de Assunção L, Leite JPV, Oliveira MGdA, Kasuya MCM (2013) Antioxidant activities, total phenolics and metal contents in Pleurotus ostreatus mushrooms enriched with iron, zinc or lithium. LWT Food Sci Technol 54(2):421-425 
Frutos I, García-Delgado C, Gárate A, Eymar E (2016) Biosorption of heavy metals by organic carbon from spent mushroom substrates and their raw materials. Int J Environ Sci Technol 13(11):2713-2720

Gabriel J, Capelari M, Rychlovský P, Krenželok M, Zadražil F (1996) Influence of cadmium on the growth of Agrocybe perfecta and two Pleurotus spp. and translocation from polluted substrate and soil to fruit bodies. Toxicol Environ Chem 56:141-146

Gunatilake SK (2015) Methods of removing heavy metals from industrial wastewater. J Multidiscip Eng Sci Stud 1(1):12-18

Henini G, Laidani Y, Fatiha Souahi F (2011) Study of adsorption of copper on biomass Pleurotus mutilus and the possibility of its regeneration by desorption. Energy Proced 6:441-448

Hlihor RM, Bulgariu L, Sobariu DL, Diaconu M, Tavares T, Gavrilescu M (2014) Recent advances in biosorption of heavy metals: support tools for biosorption equilibrium, kinetics and mechanism. Rev Roum Chim 59:527-538

Huo C-L, Shang Y-Y, Zheng J-J, He R-X, He XS (2011) The adsorption effect of three mushroom powder on $\mathrm{Cu}^{2+}$ of low concentration. In: International symposium on water resource and environmental protection 20-22 May 2011. doi: 10.1109/ISWREP.2011.5893731

Ita BN, Essien JP, Ebong GA (2006) Heavy metal levels in fruiting bodies of edible and non-edible mushrooms from the Niger delta region of Nigeria. J Agric Soc Sci 2:84-87

Ita BN, Ebong GA, Essien JP, Eduok SI (2008) Bioaccumulation potential of heavy metals in edible fungal sporocarps from the Niger delta region of Nigeria. Pak J Nutr 7:93-97

Jain SK, Gujral GS, Jha NK, Vasudevan P (1988) Heavy metal uptake by Pleurotus sajor-caju from metal-enriched duckweed substrate. Biol Wastes 24:275-282

Jain SK, Gujral GS, Vasudevan P, Jha NK (1989) Uptake of heavy metals by Azolla pinnata and their translocation onto the fruit bodies of Pleurotus sajorcaju. J Ferment Bioeng 68(1):64-67

Javaid A, Bajwa R (2007) Biosorption of Cr(III) ions from tannery wastewater by Pleurotus ostreatus. Mycopathologia 5:71-79

Javaid A, Bajwa R (2008) Biosorption of electroplating heavy metals by some basiodiomycetes. Mycopathologia 6:1-6

Javaid A, Bajwa R, Shafique U, Anwar J (2011) Removal of heavy metals by adsorption on Pleurotus ostreatus. Biomass Bioenergy 35:1675-1682

Jiang Y, Hao R, Yang S (2016) Equilibrium and kinetic studies on biosorption of $\mathrm{Pb}$ (II) by common edible macrofungi: a comparative study. Can J Microbiol 62(4):329-337

Jiang Y, Has R, Yang S (2017) Natural bioaccumulation of heavy metals onto common edible macrofungi and equilibrium and kinetic studies on biosorption of $\mathrm{Pb}$ (II) to them. Acta Nat Univ Pekin 53(1):125-134

Joo JH, Hussein KA, Hassan SHA (2011) Biosorptive capacity of Cd(II) and Pb(II) by lyophilized cells of Pleurotus eryngii. Korean J Soil Sci Fert 44:615-624

Joutey NT, Savel H, Bahafid W, El Ghachtouli N (2015) Mechanism of hexavalent chromum resistance and removal by microorganisms. Rev Environ Contam Toxicol 233:45-69

Kalac P, Svoboda L (2000) A review of trace element concentrations in edible mushrooms. Food Chem 69:273-281

Kamarudzaman AN, Tay CC, Amir A, Talib SA (2015) Biosorption of Mn(II) ions from aqueous solution by Pleurotus spent mushroom compost in a fixed-bed column. Proc Soc Behav Sci 195:2709-2716

Kapoor A, Viraraghavan T (1998) Biosorption of heavy metals on Aspergillus niger effect of pretreatment. Bioresour Technol 63:109-113

Khitous M, Moussous S, Selatnia A, Kherat M (2015) Biosorption of Cd(II) by Pleurotus mutilus biomass in fixed-bed column: experimental and breakthrough curve analysis. Desalination Water Treat 57(35):1655916570. doi:10.1080/19443994.2015.1081625

Kim HY, Yoon DH, Lee WH, Han SK, Shrestha B, Kim CH, Lim MH, Chang W, Lim S, Choi S, Song WO, Sung JM, Hwang KC, Kim TW (2007) Phellinus linteus inhibits inflammatory mediators by suppressing redox-based NF-jB and MAPKs activation in lipopolysaccharide-induced RAW 264.7 macrophage. J Ethnopharmacol 114:307-315

Klein JM, Anziliero S, Camassola M, Grisa AMC, Brandalise RN, Zeni M (2012) Evaluation of metal biosorption by the fungus Pleurotus sajor-caju on modified polyethylene films. J Bioremed Biodeg 3:152. doi:10.4172/2155-6199.1000152:5

Kocaoba S, Arisoy M (2011) The use of a white rot fungi (Pleurotus ostreatus) immobilized on Amberlite XAD-4 as a new biosorbent in trace metal determination. Bioresour Technol 102:8035-8039
Kulshreshtha S, Mathur N, Bhatnagar P (2014) Mushroom as a product and their role in mycoremediation. AMB Express 4:29. doi:10.1186/ s13568-014-0029-8

Lamrood PY, Ralegankar SD (2013) Biosorption of Cu, Zn, Fe, Cd, Pb and Ni by non treated biomass of some edible mushrooms. Asian J Exp Biol 4(2):190-195

Liew HH, Tay CC, Yong SK, Surif S, Abdul Talib S (2010) Biosorption characteristics of lead [Pb(II)] by Pleurotus ostreatus biomass. In: Abstracts of the proceedings of international conference on science and social research (CSSR), Kuala Lumpur, 2010

Majeed A, Jilani MI, Nadeem R, Hanif MA, Ansari TM (2012) Novel studies for the development of hybrid biosorbent. Int J Chem Biochem Sci 2:78-82

Majeed A, Jilani MI, Nadeem R, Hanif MA, Ansari TM (2014) Adsorption of $\mathrm{Pb}$ (II) using novel Pleurotus sajor-caju and sunflower hybrid biosorbent. Environ Prot Eng 40(2):5-15

Mandal TK, Baldrian P, Gabriel J, Nerud F, Zadraž il F (1998) Effect of mercury on the growth of wood-rotting basidiomycetes Pleurotus ostreatus, Pycnoporus cinnabarinus and Serpula lacrymans. Chemosphere 36(3):435-440

Manzi P, Aguzzi A, Pizzoferrato L (2001) Nutritional value of mushrooms widely consumed in Italy. Food Chem 73:321-325

Mosa KA, Saadoun I, Kumar K, Helmy M, Dhankher OP (2016) Potential biotechnological strategies for the cleanup of heavy metals and metalloids. Front Plant Sci 7:1-14. doi:10.3389/fpls.2016.00303

Nnorom IC, Jarzyńska G, Falandysz J, Drewnowska M, Okoye I, Oji-Nnorom CG (2012) Occurrence and accumulation of mercury in two species of wild grown Pleurotus mushrooms from southeastern Nigeria. Ecotoxicol Environ Safe 84:78-83

Nnorom IC, Jarzyńska G, Drewnowska M, Dryżałowska A, Kojta A, Pankavec S, Falandysz J (2013) Major and trace elements in sclerotium of Pleurotus tuber-regium (Ósū) mushroom—dietary intake and risk in southeastern Nigeria. J Food Compos Anal 29(1):73-81

Ogbo EM, Okhuoya JA (2011) Bio-absorption of some heavy metals by Pleurotus tuber-regium Fr. Singer (an edible mushroom) from crude oil polluted soils amended with fertilizers and cellulosic wastes. Int J Soil Sci 6:34-48

Oghenekaro AO, Okhuoya JA, Akpaja EO (2008) Growth of Pleurotus tuberregium (Fr) Singer on some heavy metal-supplemented substrates. Afr J Microbiol Res 2:268-271

Osman MS, Bandyopadhyay M (1999) Bioseparation of lead ions from wastewater by using a fungus P. ostreatus. J Civil Eng 27:183-196

Oyetayo VO, Adebayo AO, Ibileye A (2012) Assessment of the biosorption potential of heavy metals by Pleurotus tuber-regium. Int J Adv Biol Res 2:293-297

Özdemir S, Okumuşa V, Kilınçb E, Bilgetekinc H, Dündara A, Ziyadanog`ullarıb B (2012) Pleurotus eryngii immobilized Amberlite XAD-16 as a solid-phase biosorbent for preconcentrations of $\mathrm{Cd}^{2+}$ and $\mathrm{Co}^{2+}$ and their determination by ICP-OES. Talanta 99:502-506

Palmieri G, Giardina P, Bianco C, Bianca F, Sannia G (2000) Copper induction of lactase isoenzymes in the ligninolytic fungus Pleurotus ostreatus. Environ Microbiol 66(3):920-924

Prakash V (2017) Mycoremediation of environmental pollutants. Int J Chem Tech Res 10(3):149-155

Prasad ASA, Varatharaju G, Anushri C, Dhivyasree S (2013) Biosorption of lead by Pleurotus florida and Trichoderma viride. Br Biotechnol J 3(1):66-78

Puentes-Cárdenas IJ, Pedroza-Rodríguez AM, Navarrete-López M, VillegasGarrido TL, Cristiani-Urbina E (2012) Biosorption of trivalent chromium from aqueous solutions by Pleurotus ostreatus biomass. Environ Eng Manag J 11(10):1741-1752

Purkayastha RP, Mitra AK, Bhattacharyya B (1994) Uptake and toxicological effects of some heavy metals on Pleurotus sajor-caju (Fr.) Singer. Ecotoxicol Environ Safe 27:7-13

Qazilbash AA (2004) Isolation and characterization of heavy metal tolerant biota from industrially polluted soils and their role in bioremediation. Biol Sci 41:210-256

Quarcoo A, Adotey G (2013) Determination of heavy metals in Pleurotus ostreatus (Oyster mushroom) and Termitomyces clypeatus (Termite mushroom) sold on selected markets in Accra, Ghana. Mycosphere 4(5):960-967

Radulescu C, Stihi C, Busuioc G, Gheboianu Al, Popescu IV (2010) Studies concerning heavy metals bioaccumulation of wild edible mushrooms from industrial area by using spectrometric techniques. Bull Environ Contam Toxicol 84:641-646 
Raj DD, Mohan B, Vidya Shetty BM (2011) Mushrooms in the remediation of heavy metals from soil. Int J Environ Pollut Control Manag 3(1):89-101

Ruiz-Duenas FJ, Guille'n F, Camarero S, Pe'rez-Boada M, Martı'nez MJ, Martı́nez AT (1999) Regulation of peroxidase transcript levels in liquid cultures of the ligninolytic fungus Pleurotus eryngii. Appl Environ Microbiol 65:4458-4463

Salman HA, Ibrahim MI, Tarek MM, Abbas HS (2014) Biosorption of heavy metals - a review. J Chem Sci Technol 3(4):74-102

Sarikurkcu C, Tepe B, Yamac M (2008) Evaluation of the antioxidant activity of four edible mushrooms from the Central Anatolia, EskisehirTurkey: Lactarius deterrimus, Suillus collitinus, Boletus edulis, Xerocomus chrysenteron. Bioresour Technol 99:6651-6655. doi:10.1016/j. biortech.2007.11.062

Singh J, Kant K, Sharma HB, Rana KS (2008) Bioaccumulation of cadmium in tissues of Cirrihna mrigala and Catla catla. Asian J Exp Sci 22:411-414

Soden DM, Dobson ADW (2001) Differential regulation of laccase gene expression in Pleurotus sajor-caju. Microbiology 147:1755-1763

Suseem SR, Mary Saral A (2014) Biosorption of heavy metals using Pleurotus eous. J Chem Pharm Res 6(7):2163-2168

Synytsya A, Mickova K, Synytsya A, Jablonsky I, Spevacek J, Erban V (2009) Glucans from fruit bodies of cultivated mushrooms Pleurotus ostreatus and Pleurotus eryngii: structure and potential prebiotic activity. Carbohydr Polym 76:548-556. doi:10.1016/j.carbpol.2008.11.02

Tay CC, Redzwan G, Liew HH, Yong SK, Surif S, Abdul-Talib S Copper (II) (2010) Biosorption characteristic of Pleurotus spent mushroom compost. In: International conference on science and social research (CSSR 2010), Kuala Lumpur, Malaysia, Dec 5-7, 2010

Tay CC, Liew HH, Yong SK, Surif S, Abdul-Talib S (2009) Biosorption of lead(II) from aqueous solutions by Pleurotus as a toxicity biosorbent. In: Environmental science and technology conference (ESTEC2009), Kuala Terengganu Malaysia, Dec 7-8, 2009

Tay CC, Liew HH, Yin C-Y, Abdul-Talib S, Surif S, Abdullah A, Yong SK (2011) Biosorption of cadmium ions using Pleurotus ostreatus: growth kinetics, isotherm study and biosorption mechanism. Kor J Chem Eng 28(3):825-830

Tay CC, Redzwan G, Liew HH, Yong SK, Surif S, Abdul-Talib S (2012) Fundamental behavior for biosorption of divalence cations by Pleurotus mushroom spent-substrate. Malays J Sci 31:40-44
Tay CC, Liew HH, Abdul-Talib S, Redzwan G (2016) Bi-metal biosorption using Pleurotus ostreatus spent mushroom substrate (PSMS) as a biosorbent: isotherm, kinetic, thermodynamic studies and mechanism. Desalination Water Treat 57(20). http://www.tandfonline.com/action/showCitFormats?. doi: http://dx.doi.org/10.1080/19443994.2015.1027957

Velásquez L, Dussan J (2009) Biosorption and bioaccumulation of heavy metals on dead and living biomass of Bacillus sphaericus. J Hazard Mater 167:713-716. doi:10.1016/j.jhazmat.2009.01.044

Vimala R, Das N (2011) Mechanism of Cd(II) adsorption by macrofungus Pleurotus platypus. J Environ Sci 23:288-293

Vimala R, Charumathi D, Nilanjana Das (2011) Packed bed column studies on $\mathrm{Cd}(\mathrm{II})$ removal from industrial wastewater by macrofungs Pleurotus platypus. Desalination 275:291-296

Wu M, Xu Y, Ding W, Li Y, Xu H (2016) Mycoremediation of manganese and phenanthrene by Pleurotus eryngii mycelium enhanced by tween 80 and saponin. Appl Microbiol Biotechnol 100:7249-7261

Xiangliang P, Jianlong W, Daoyong Z (2005) Biosorption of Pb(II) by Pleurotus ostreatus immobilized in calcium alginate gel. Process Bio Chem 40:2799-2803

Xiangliang P, Jianlong W, Daoyong Z (2009) Biosorption of Co(II) by immobilised Pleurotus ostreatus. Int J Environ Pollut 37:289-298

Xu F, Liu X, Chen Y, Zhang K, Xu H (2016) Self-assembly modified-mushroom nano composite for rapid removal of hexavalent chromium from aqueous solution with bubbling fluidized bed. Sci Rep 6. 26201. doi: 10.1038/srep26201. http://www.nature.com/articles/srep26201

Yalçinkaya Y, Arica MY, Soysal L, Bektaş S (2002) Cadmium and mercury uptake by immobilized Pleurotus sapidus. Turk J Chem 26(3):441-452

Yang T, Chen M-L, Wang J-H (2015) Genetic and chemical modification of cells for selective separation and analysis of heavy metals of biological or environmental significance. TrAC Trends Anal Chem 66:90-102

Yazdani M, Chee KY, Faridah A, Soon GT (2010) An in vitro study on the adsorption, absorption and uptake capacity of $\mathrm{Zn}$ by the bioremediator Trichodermaatro viride. Environ Asia 3:53-59

Zhu FK, Qu L, Fan WX, Qiao MY, Hao HL, Wang XJ (2010) Assessment of heavy metals in some wild edible mushrooms collected from Yunnan Province, China. Environ Monit Assess 30:61-62

\section{Submit your manuscript to a SpringerOpen ${ }^{\circ}$ journal and benefit from:}

- Convenient online submission

- Rigorous peer review

- Open access: articles freely available online

- High visibility within the field

- Retaining the copyright to your article

Submit your next manuscript at $\boldsymbol{\nabla}$ springeropen.com 